\title{
The acute effects of thymoquinone on acute peripheral nerve injury: an experimental study
}

\author{
İsmail Gülşen, M.D., ${ }^{1}$ Hakan Ak, M.D., ${ }^{2}$ Mikail Kara, M.D., ${ }^{3}$ Abdulsemat Gökalp, M.D., ${ }^{4}$ \\ Veysel Akyol, M.D., ${ }^{3}$ Ömer Faruk Koçak, M.D., ${ }^{5}$ Murat Çetin Rağbetli, M.D. ${ }^{3}$
}

\author{
1Department of Neurosurgery, Yüzüncü Yıl University Faculty of Medicine, Van-Turkey \\ ${ }^{2}$ Department of Neurosurgery, Bozok University Faculty of Medicine, Yozgat-Turkey \\ ${ }^{3}$ Department of Histology, Yüzüncü Yıl University Faculty of Medicine, Van-Turkey \\ ${ }^{4}$ Department of Neurosurgery, Tatvan State Hospital, Bitlis-Turkey \\ ${ }^{5}$ Department of Plastic and Reconstructive Surgery, Yüzüncü Yıl University Faculty of Medicine, Van-Turkey
}

\section{ABSTRACT}

BACKGROUND: The purpose of this study was to evaluate the acute effects of thymoquinone (TQ) on acute nerve injury.

METHODS: A rat model of crush injury of the sciatic nerve was used. Animals were divided into 3 groups: control, trauma, and TQ treatment groups ( $n=6$ per group). Seven days after injury, sciatic nerve specimens were obtained from the site of the injury and analyzed histologically and stereologically. Axon diameter, myelin thickness, and axon density were measured.

RESULTS: There were no significant differences in axon diameter, myelin thickness, or axon density among groups.

CONCLUSION: TQ has no acute therapeutic effect on acute nerve injury.

Keywords: Axon wdensity; myelin thickness; sciatic nerve; thymoquinone.

\section{INTRODUCTION}

The management of acute peripheral nerve injury is unsatisfactory, particularly in patients who are not good candidates for surgery. Levels of free oxygen radicals increase after peripheral nerve injury due to tissue destruction, which leads to further tissue damage. In order to better treat acute peripheral nerve injury, several chemical agents with antioxidant effects have been evaluated for their ability to inhibit this cascade..$^{[1-3]}$

Thymoquinone (TQ, ClOHI2O2, 2-isopropyl-5-methylbenzo-I,4-quinone) is a bioactive phytochemical compound found in the seeds of Nigella sativa. ${ }^{[4,5]}$ Several studies have re-

Address for correspondence: İsmail Gülşen, M.D.
Yüzüncü Yıl Üniversitesi Dursun Odabaş Tıp Merkezi, Beyin ve Sinir
Cerrahisi Anabilim Dalı, 65080 Van, Turkey
$\begin{array}{ll}\text { Tel: +90 } 432 \text { - 216 } 8352 \quad \text { E-mail: dr-ismailgulsen@hotmail.com } \\ \text { Qucik Response Code } & \text { Ulus Travma Acil Cerrahi Derg } \\ & \text { 2016;22(6) } \\ & \text { doi: } 10.5505 / \text { tjtes.2016.40204 } \\ \end{array}$

ported that it exhibits anticarcinogenic, antioxidant, anti-inflammatory, and antiepileptic properties. ${ }^{[6-9]}$ However, studies analyzing the effects of TQ on the peripheral nervous system have focused only on models of neuropathic pain. ${ }^{[10,11]}$ To the best of our knowledge, no studies have assessed therapeutic effects of TQ on peripheral nerves following an acute crush injury.

The aim of the present study was to evaluate the acute effects of TQ on the sciatic nerve following an acute crush injury using histological and stereological methods.

\section{MATERIALS AND METHODS}

This study was performed after receiving approval from the ethics committee on use of laboratory animals of Yüzüncü Yıl University (YÜHADYEK; date: 09/05/20I4; approval number: $2014 / 10)$. Female adult Wistar albino rats $(n=18)$ weighing $250 \pm 20 \mathrm{~g}$ were divided into 3 groups of 6 animals. All animals were weighed before the operation and before sacrifice. For anesthesia, $8 \mathrm{mg}$ ketamine (Alfamine 10\%; Alfasan International BV, Woerden, Netherlands) and I mg xylazine per $100 \mathrm{~g}$ body weight (Alfazyne 2\%; Alfasan International BV, Woerden, Netherlands) were administered intraperitoneally. Surgery was performed on the left sciatic nerve of all animals. 
Control group $(n=6)$ underwent only sciatic nerve dissection. In the acute crush model group $(n=6)$, the sciatic nerve was dissected and then clamped for 30 seconds using medium pressure aneurysm clip. TQ treatment group $(n=6)$ underwent the same surgical procedure as the acute crush model group and were injected intraperitoneally with $5 \mathrm{mg} / \mathrm{kg} / \mathrm{day}$ TQ for 7 days. On day 8, all animals were sacrificed, and the sciatic nerve was excised approximately $5 \mathrm{~mm}$ proximal and distal from the lesion at the site of injury. TQ, thiobarbituric acid, Ellman's reagent (DTNB, 5-5'-dithiobis-[2-nitrobenzoic acid]) and bovine serum albumin were purchased from Sigma Chemical Co. (St. Louis, MO, USA).

\section{Histology and Stereology}

For the stereological analysis, the left sciatic nerve of each animal was exposed, and nerve segment $4 \mathrm{~mm}$ in length was carefully removed. Segments were cut into blocks of equal length and then fixed using $2.5 \%$ glutaraldehyde in $0.1 \mathrm{M}$ sodium cacodylate buffer $(\mathrm{pH} 7.4)$ for 20 hours. After fixation, tissues were rinsed twice in sodium cacodylate buffer, and then postfixed in $1 \%$ osmium tetroxide for $11 / 2$ hours. Peripheral nerves were dehydrated in an ascending alcohol series, placed in propylene oxide twice, and embedded in epoxy resin. For light microscopy, semi-thin sections of $750 \mathrm{~nm}$ were obtained using an Ultracut UCT ultramicrotome (Leica Microsystems $\mathrm{GmbH}$, Wetzler, Germany) and then stained with modified toluidine blue solution ( $1 \%$ toluidine blue and $2 \%$ borate in distilled water). ${ }^{[12,13]}$ Researchers blinded to the groups analyzed the peripheral nerves stereologically according to method described by Turgut et al. ${ }^{[12]}$ Only I section was obtained from each sciatic nerve. An unbiased counting frame sized 2500 $\mu \mathrm{m} 2$ was used. Area sampling of sciatic nerve section was done with a 1/6 proportion and systematic random sampling steps. Cross-sections of all axon profiles were sampled, regardless of their shape. A light microscope (BX53F; Olympus Corp., Tokyo, Japan) with a CCD color video camera (JVC/ Victor Company of Japan, Ltd, Yokohama, Japan) was used at a magnification of 1000 ( $\times 100$ oil objective; N.A.: I.25). Total axon number in each peripheral nerve was estimated by normalizing the number of axons counted in entire area. Unbiased disector/Cavalieri combination stereological method was used, which is advantageous in that it is influenced less by technical artifacts and section thickness (Figure I). ${ }^{[14]}$ The following formula was used to assess axon numbers:

$\mathrm{N}=\overline{\mathrm{Q}}-\times \sum \mathrm{P} \times \mathrm{k} \times \frac{a / p}{\mathrm{a}(\text { frame })}$,

$\mathrm{N}=$ total axon number density, $\overline{\mathrm{Q}}^{-=}$the mean axon number, $\sum \mathrm{P}=$ the total point number, $\mathrm{k}=$ the section sequence, $\mathrm{a} / \mathrm{p}=$ the point area, and $\mathrm{a}_{\text {(frame) }}=$ the frame area counted.

\section{Statistical Analysis}

Shapiro-Wilk test and Levene's test were used to test normality and homogeneity of the data. One-way analysis of variance was used to compare continuous variables. Values were

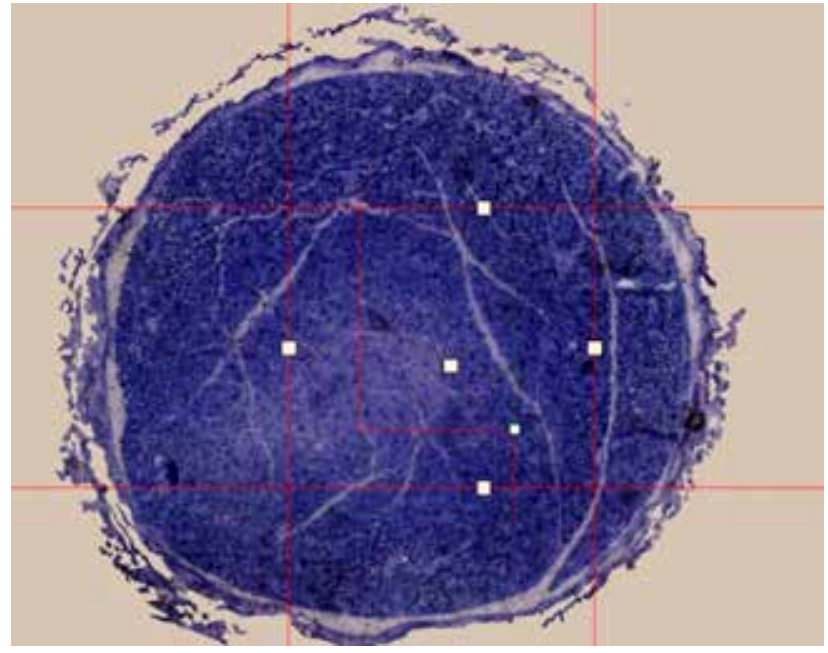

Figure 1. A section of the sciatic nerve ( $\times 10$ magnification).

expressed as frequency and percentage, mean \pm standard deviation, or median and interquartile range. Statistical analyses were performed using SPSS version I5.0 (SPSS Inc., Chicago, IL, USA), and the level of statistical significance was set at $p<0.05$.

\section{RESULTS}

Mean axon diameters were $3.60 \mu \mathrm{m}$ (range: 3.2-3.86 $\mu \mathrm{m}$ ), $4.4 \mathrm{I}$ $\mu \mathrm{m}$ (range: $4.0-5.15 \mu \mathrm{m}$ ), and $4.40 \mu \mathrm{m}$ (range: $3.53-5.06 \mu \mathrm{m}$ ) in the control, trauma, and TQ groups, respectively. There was a statistically significant difference between control and trauma groups $(p=0.013)$. A similar significant difference was observed between control and TQ groups $(p=0.014)$. However, there was no statistically significant difference between trauma and TQ groups $(p=0.99)$.

Mean myelin thickness was I.3। $\mu \mathrm{m}$ (range: I.0-1.7 $\mu \mathrm{m}$ ), I.6। $\mu \mathrm{m}$ (range: $1.45-1.75 \mu \mathrm{m}$ ), and $1.87 \mu \mathrm{m}$ (range: $1.45-2.27$

Table I. Axon diameter, myelin thickness, and axon density

\begin{tabular}{llcc}
\hline & Group & n & Mean \pm SD \\
\hline Axon diameter & Group I & 6 & $3.60 \pm 0.24$ \\
& Group 2 & 6 & $4.41 \pm 0.44$ \\
& Group 3 & 6 & $4.40 \pm 0.53$ \\
& Total & 18 & $4.13 \pm 0.55$ \\
Myelin thickness & Group 1 & 6 & $1.31 \pm 0.22$ \\
& Group 2 & 6 & $1.61 \pm 0.11$ \\
& Group 3 & 6 & $1.87 \pm 0.30$ \\
& Total & 18 & $1.60 \pm 0.31$ \\
& Group 1 & 6 & $563 \pm 120$ \\
& Group 2 & 6 & $801 \pm 160$ \\
& Group 3 & 6 & $805 \pm 140$ \\
& Total & 18 & $635 \pm 116$ \\
\hline
\end{tabular}

SD: Standard deviation. 
Table 2. Results of the statistical analyses performed

\begin{tabular}{|c|c|c|c|}
\hline \multirow[b]{2}{*}{ Axon diameter } & \multicolumn{2}{|c|}{ Groups } & \multirow{2}{*}{$\frac{\mathbf{p}}{0.013}$} \\
\hline & 1 & 2 & \\
\hline & & 3 & 0.014 \\
\hline & 2 & I & 0.013 \\
\hline & & 3 & 0.999 \\
\hline & 3 & I & 0.014 \\
\hline & & 2 & 0.999 \\
\hline \multirow[t]{6}{*}{ Myelin thickness } & 1 & 2 & 0.087 \\
\hline & & 3 & 0.002 \\
\hline & 2 & I & 0.087 \\
\hline & & 3 & 0.154 \\
\hline & 3 & I & 0.002 \\
\hline & & 2 & 0.154 \\
\hline \multirow[t]{6}{*}{ Axon density } & I & 2 & 0.152 \\
\hline & & 3 & 0.981 \\
\hline & 2 & I & 0.152 \\
\hline & & 3 & 0.111 \\
\hline & 3 & I & 0.981 \\
\hline & & 2 & 0.111 \\
\hline
\end{tabular}

$\mu \mathrm{m})$ in control, trauma, and TQ groups, respectively. There was no statistically significant difference between control and trauma groups; slight increase observed in trauma group was likely due to an edematous effect $(p=0.087)$. Although there was a statistically significant difference between control and TQ groups $(p=0.002)$, there was no statistically significant difference between trauma and TQ groups $(p=0.15)$.

Axon density was 563 (range: 243-887), 80I (range: 497956), and 805 (range: 400-960) in control, trauma, and TQ groups, respectively. There were no statistically significant dif-

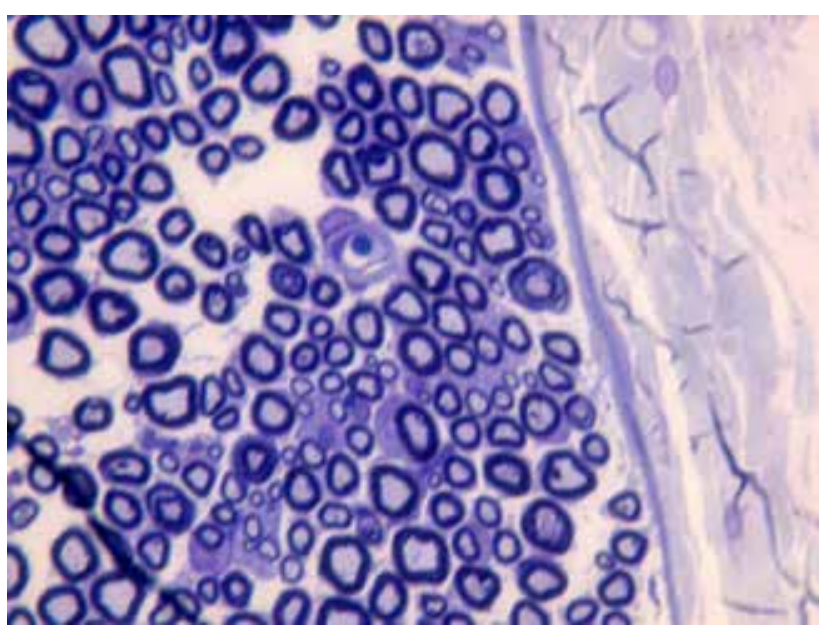

Figure 2. Micrographs of a cross-section of the trauma-inflicted area of the sciatic nerve. Images revealed vacuolization of myelin sheath. Toluidine blue staining is shown (scale bar=10 $\mu \mathrm{m}$ ). ferences between control and trauma groups or control and TQ groups ( $p=0.15$ and 0.98 , respectively). Similarly, there was no significant difference between trauma and TQ groups $(p=0.1 \mathrm{I})$ (Table I and 2). Neuronal degeneration rates were $80 \%, 90 \%$, and $90 \%$ in control, trauma, and TQ groups, respectively. There was no statistically significant difference between trauma and TQ groups (Figures 2-4).

\section{DISCUSSION}

The present study demonstrated that TQ has no therapeutic effect on acute peripheral nerve injury. Previous studies reported that TQ was a promising agent because of its anticarcinogenic, antioxidant, and antiepileptic properties. ${ }^{[6-8]}$ Therapeutic effects of TQ have been evaluated in a wide variety of different systems, including lipid and cholesterol metabolism, glucose metabolism (antidiabetic), and the gastrointestinal, circulatory, and peripheral nervous systems, as well as its antioxidant and anticarcinogenic effects.

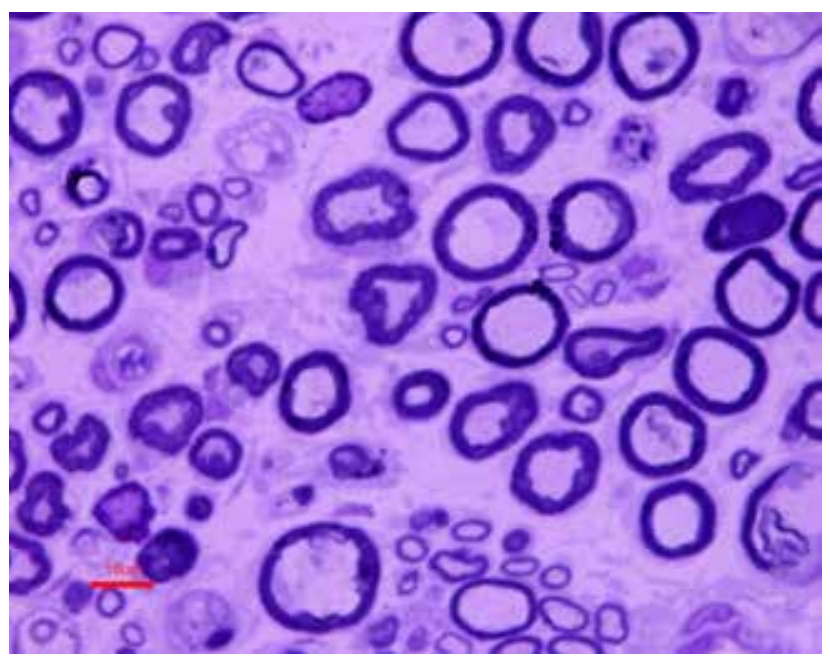

Figure 3. Micrographs of a cross-section of the sciatic nerve in the sham group; the myelin sheaths were intact. Toluidine blue staining is shown (magnification $\times 100$, oil immersion).

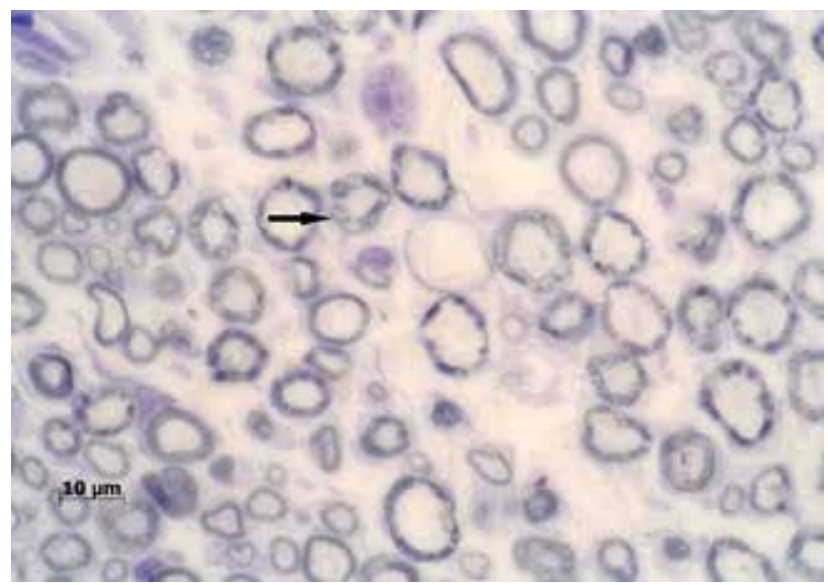

Figure 4. Micrographs of a cross-section of the sciatic nerve in the TQ group; the myelin sheath exhibits vacuolization and degeneration (black arrow). Toluidine blue staining is shown (magnification $\times 100$, oil immersion; scale bar $=10 \mu \mathrm{m}$ ). 
Regarding lipid and cholesterol metabolism, TQ decreases levels of total cholesterol and low-density lipoprotein and increases the level of high-density lipoprotein; therefore, it reduces the risk of cardiovascular disease development. ${ }^{[15,16]}$

Effects of TQ on glucose metabolism have been reported in various studies, but the data are conflicting. For example, Hawsawi et al. reported that TQ reduces blood glucose levels in normal rats, ${ }^{[17]}$ and similar results were reported in normal and alloxan-induced diabetic rabbits, alloxan-induced diabetic rats, and human subjects. ${ }^{[18-2 \mid]}$ However, 2 different studies reported that TQ did not change fasting blood glucose levels significantly in normal or streptozotocin-induced diabetic rats. ${ }^{[22,23]}$ Although the reason for these differing effects is unclear, TQ might cause hypoglycemia in 2 ways. First, it increases glucose usage by increasing insulin secretion. Second, TQ might decrease hepatic gluconeogenesis. ${ }^{[24]}$ In another study, Kanter et al. reported that TQ had protective therapeutic effects on diabetes by decreasing oxidative stress and preserving pancreatic $\beta$-cell integrity; therefore, the authors concluded that TQ might be useful clinically for protecting $\beta$-cells from oxidative stress. ${ }^{[25]}$

TQ exerts gastroprotective and hepatoprotective effects on the gastrointestinal system. A previous study reported that TQ could protect gastric mucosa from acute alcohol-induced mucosal injury, and that this gastroprotective effect might be induced by its radical-scavenging activity. ${ }^{[26]}$ In addition, hepatoprotective effects of TQ against several hepatotoxic agents have been reported, which were attributed to its antioxidant activity. ${ }^{[27-29]}$ It was also reported that TQ could be used to treat ethanol-induced hepatotoxicity because of its antioxidant and anti-inflammatory effects. ${ }^{[30]}$

Several antioxidant effects of TQ have been reported. For example, TQ is a potent scavenger of many reactive oxygen species, including superoxide radicals and hydroxyl radicals. It also inhibits the formation of free radicals by inhibiting the activity of 5-lipoxygenase and 5-hidroxyicosatetraenoic acid. ${ }^{[7,31]}$

In the cardiovascular system, TQ dose-dependently decreased arterial blood pressure and heart rate in a rat model. ${ }^{[32]} \mathrm{TQ}$ has also been reported to have anticarcinogenic effects by blocking tumor cell progression via apoptosis of cells in GI phase of the cell cycle in breast, ovary, colorectal, osteosarcoma, fibrosarcoma, lung, and prostate cancers. ${ }^{[33-37]}$

Effects of TQ on the peripheral nervous system were reported in 3 studies. ${ }^{[10,11]}$ The first of these was performed in an experimental streptozotocin-induced diabetic neuropathy model. The authors reported that TQ improved ultrastructural features of axons remarkably. ${ }^{[10]}$ In the second study, Amin et al. used a rat model of chronic neuropathy and concluded that TQ plays an anti-nociceptive role, possibly by exerting antioxidant effects and inhibiting microglial activity. [II] However, no published studies have assessed the acute ef- fects of TQ in a peripheral nerve model. Current histological and stereological results suggest that TQ has no therapeutic effect on acute nerve injury.

\section{Conclusion}

TQ has no beneficial acute effects on acute nerve injury, despite its reported antioxidant and anti-inflammatory effects. However, our results should be confirmed by large-scale experimental studies.

\section{Acknowledgements}

None

Conflict of interest: None declared.

\section{REFERENCES}

1. Senoglu M, Nacitarhan V, Kurutas EB, Senoglu N, Altun I, Atli Y, et al. Intraperitoneal Alpha-Lipoic Acid to prevent neural damage after crush injury to the rat sciatic nerve. J Brachial Plex Peripher Nerve Inj 2009;4:22.

2. Yllmaz Z, Senoglu M, Kurutas EB, Ciralik H, Ozbağ D. Neuroprotective Effects of Mannitol and Vitamin C on crush injury of sciatic Nerve. An experimental rat study. J Neurol Sci Turk 2011;28:538-51.

3. Yalçın SS, Ak H, Aydın V, Serter M, Göçmen AY. Evaluation of the acute period effects of nicergoline in the management of acute peripheral nerve injury. J Neurol Sci Turk 2013;30:651-9.

4. Pari L, Sankaranarayanan C. Beneficial effects of thymoquinone on hepatic key enzymes in streptozotocin-nicotinamide induced diabetic rats. Life Sci 2009;85:830-4. Crossref

5. Abukhader MM. The effect of route of administration in thymoquinone toxicity in male and female rats. Indian J Pharm Sci 2012;74:195-200.

6. Gali-Muhtasib H, Roessner A, Schneider-Stock R. Thymoquinone: a promising anti-cancer drug from natural sources. Int J Biochem Cell Biol 2006;38:1249-53. Crossref

7. Badary OA, Taha RA, Gamal el-Din AM, Abdel-Wahab MH. Thymoquinone is a potent superoxide anion scavenger. Drug Chem Toxicol 2003;26:87-98. Crossref

8. Akhondian J, Kianifar H, Raoofziaee M, Moayedpour A, Toosi MB, Khajedaluee M. The effect of thymoquinone on intractable pediatric seizures (pilot study). Epilepsy Res 2011;93:39-43. Crossref

9. Alsarf MA. Effect of thymoquinone on ethanol-induced hepatotoxicity in Wistwar rats. J of Med Sci 2007;7:1164-70. Crossref

10. Kanter M. Effects of Nigella sativa and its major constituent, thymoquinone on sciatic nerves in experimental diabetic neuropathy. Neurochem Res 2008;33:87-96. Crossref

11. Amin B, Taheri MM, Hosseinzadeh H. Effects of intraperitoneal thymoquinone on chronic neuropathic pain in rats. Planta Med 2014;80:126977. Crossref

12. Turgut M, Kaplan S, Unal BZ, Bozkurt M, Yürüker S, Yenisey C, et al. Stereological analysis of sciatic nerve in chickens following neonatal pinealectomy: an experimental study. J Brachial Plex Peripher Nerve Inj 2010;5:10.

13. Woods AE, Stirling JW. Electron microscopy. In: Bancroft JD, Gamble $\mathrm{M}$, editors. Theory and pratice of histological techniques. China: Churchill Livingstone Elsevier; 2008. p. 611. Crossref

14. Pakkenberg B, Gundersen HJ. Total number of neurons and glial cells in human brain nuclei estimated by the disector and the fractionator. J Microsc 1988;150:1-20. Crossref

15. Al-Naqeep G, Ismall M, Yazan LS. Effects of thymoquinone rich fraction 
and thymoquinone on plasma lipoprotein levels and hepatic low density lipoprotein receptor and 3-hydroxy-3-methylglutaryl coenzyme A reductase genes expression. Journal of Functional Foods 2009;1:298-303.

16. Nofer J. HDL and arteriosclerosis: beyond reverse cholesterol transport. Atherosclerosis 2002;161:1-16. Crossref

17. Hawsawi ZA, Ali BA, Bamosa AO. Effect of Nigella sativa (Black Seed) and thymoquinone on blood glucose in albino rats. Ann Saudi Med 2001;21:242-4.

18. Al-Hader A, Aqel M, Hassan Z. Hypoglycemic effects of the volatile oil of Nigella sativa seeds. Int J Pharmacol 1993;31:96-100. Crossref

19. Kanter M. Protective effects of thymoquinone on streptozotocin-induced diabetic nephropathy. J Mol Histol 2009;40:107-15. Crossref

20. Eskander H, Emad F, Won Jun A, Ibrahim K, Abelal WE. Hypoglycemic effect of a herbal formulation in alloxan-induced diabetic rats. Egypt J Pharm Sci 1995;36:253-70.

21. Bamosa A, Ali BA, Sowayan S. Effect of oral ingestion of Nigella sativa seeds on some blood parameters. Saudi Pharmacol J 1997;5:126-9.

22. Al-Awadi FM, Gumaa KA. Studies on the activity of individual plants of an antidiabetic plant mixture. Acta Diabetol 1987;24:7-41. Crossref

23. El-Naggar AM, El-Deib AM. A study of some biological activities of Nigella sativa (black seeds) “Habat El Baraka." J Egypt Soc Pharmacol Exp Ther 1992;11:781-99.

24. Fararh KM, Shimizu Y, Shiina T, Nikami H, Ghanem MM, Takewaki T. Thymoquinone reduces hepatic glucose production in diabetic hamsters. Res Vet Sci 2005;79:219-23. Crossref

25. Kanter M. Protective effects of thymoquinone on $\beta$-cell damage in streptozotocin-induced diabetic rats. Tip Araştırmaları Dergisi 2009;7:6470.

26. Kanter M, Demir H, Karakaya C, Ozbek H. Gastroprotective activity of Nigella sativa L oil and its constituent, thymoquinone against acute alcohol-induced gastric mucosal injury in rats. World J Gastroenterol 2005;11:6662-6. Crossref

27. Al-Gharably N, Badary O, Nag1 MN, Al-Shabanah OA, Al-Sawaf HA, Al-Rikabı AC, Al-Bekarr1 AM. Protective effect of thymoquinone against carbotetrachloride induced hepatotoxicity in mice. Res Commun Pharmacol Toxicol 1997;2:41-50.

28. Aycan IÖ, Tüfek A, Tokgöz O, Evliyaoğlu O, Fırat U, Kavak GÖ, et al. Thymoquinone treatment against acetaminophen-induced hepatotoxicity in rats. Int J Surg 2014;12:213-8. Crossref

29. Suddek GM. Protective role of thymoquinone against liver damage induced by tamoxifen in female rats. Can J Physiol Pharmacol 2014;92:640-4. Crossref

30. Alsaif MA. Effect of thymoquinone on ethanol-induced hepatotoxicity in Wistar rats. J of Med Sci 2007;7:1164-70. Crossref

31. El-Dakhakhny M, Madi NJ, Lembert N, Ammon HP. Nigella sativa oil, nigellone and derived thymoquinone inhibit synthesis of 5-lipoxygenase products in polymorphonuclear leukocytes from rats. J Ethnopharmacol 2002;81:161-4. Crossref

32. el Tahir KE, Ashour MM, al-Harbi MM. The cardiovascular actions of the volatile oil of the black seed (Nigella sativa) in rats: elucidation of the mechanism of action. Gen Pharmacol 1993;24:1123-31. Crossref

33. Shoieb AM, Elgayyar M, Dudrick PS, Bell JL, Tithof PK. In vitro inhibition of growth and induction of apoptosis in cancer cell lines by thymoquinone. Int J Oncol 2003;22:107-13. Crossref

34. Gali-Muhtasib H, Diab-Assaf M, Boltze C, Al-Hmaira J, Hartig R, Roessner A, et al. Thymoquinone extracted from black seed triggers apoptotic cell death in human colorectal cancer cells via a $\mathrm{p} 53$-dependent mechanism. Int J Oncol 2004;25:857-66.

35. Roepke M, Diestel A, Bajbouj K, Walluscheck D, Schonfeld P, Roessner A, et al. Lack of p53 augments thymoquinone-induced apoptosis and caspase activation in human osteosarcoma cells. Cancer Biol Ther 2007;6:160-9. Crossref

36. Kaseb AO, Chinnakannu K, Chen D, Sivanandam A, Tejwani S, Menon $\mathrm{M}$, et al. Androgen receptor and E2F-1 targeted thymoquinone therapy for hormone-refractory prostate cancer. Cancer Res 2007;67:7782-8.

37. Motaghed M, Al-Hassan FM, Hamid SS. Thymoquinone regulates gene expression levels in the estrogen metabolic and interferon pathways in MCF7 breast cancer cells. Int J Mol Med 2014;33:8-16.

\title{
DENEYSEL ÇALIŞMA - ÖZET
}

\section{Timokinonun akut periferik sinir hasarı üzerine akut etkisi: Deneysel bir çalışma \\ Dr. İsmail Gülşen, ${ }^{1}$ Dr. Hakan Ak, ${ }^{2}$ Dr. Mikail Kara, ${ }^{3}$ Dr. Abdulsemat Gökalp, ${ }^{4}$ Dr. Veysel Akyol, ${ }^{3}$ Dr. Ömer Faruk Koçak, ${ }^{5}$ Dr. Murat Çetin Rağbetli ${ }^{3}$}

\author{
${ }^{1}$ Yüzüncü Yıl Üniversitesi Tıp Fakültesi, Beyin ve Sinir Cerrahisi Anabilim Dalı, Van \\ ${ }^{2}$ Bozok Üniversitesi Tıp Fakültesi, Beyin ve Sinir Cerrahisi Anabilim Dalı, Yozgat \\ ${ }^{3}$ Yüzüncü Yıl Üniversitesi Tıp Fakültesi, Histoloji ve Embriyoloji Anabilim Dalı, Van \\ ${ }^{4}$ Bitlis Tatvan Devlet Hastanesi, Beyin ve Sinir Cerrahisi Kliniği, Bitlis \\ ${ }^{5}$ Yüzüncü Yıl Üniversitesi Tıp Fakültesi, Plastik ve Rekonstruktif Cerrahi Anabilim Dalı, Van
}

AMAÇ: Bu çalışmanın amacı akut sinir hasarında timokinonun akut dönem etkilerini değerlendirmektir.

GEREÇ VE YÖNTEM: Çalışma sıçan sinirinde siyatik sinirde ezilme modeli geliştirilerek yapıldı. Sıçanlar kontrol, travma ve timokinon tedavi grubu olmak üzere üç gruba ayrıldı $(n=6)$. Sinir hasarından yedi gün sonra hasar yerinden siyatik sinir doku örnekleri alındı. Bu doku örneklerinde histolojik ve steryolojik çalışma yapıldı. Akson çapı, myelin kalınlığı ve akson yoğunluk ölçümleri yapıldı.

BULGULAR: Gruplar arasında akson çapı, miyelin kalınlığı ve akson yoğunluğu bakımından anlamlı bir farklılık görülmedi.

TARTIŞMA: Timokinon akut sinir hasarı üzerinde akut dönemde iyileştirici etkiye sahip değildir.

Anahtar sözcükler: Akson; akson yoğunluğu; miyelin kalınlığl; siyatik sinir; timokinon.

Ulus Travma Acil Cerrahi Derg 20। 6;22(6):526-530 doi: 10.5505/tjtes.20।6.40204 